Ligia Carla dos Santos Diniz

\title{
A História Universal e a Providência Divina nas visões de Flávio Josefo e Eusébio de Cesareia.
}

Monografia apresentada à Graduação em História da PUC-Rio como requisito para obtenção do título de Licenciatura em História.

Orientador: Professor Marcos Guedes Veneu

Rio de Janeiro

Dezembro 2017 


\section{Agradecimentos:}

Ao meu Deus a Pai, o Soberano Senhor Jeová, que por toda minha vida me deu sua direção, proteção e agora a oportunidade de dialogar com as suas escrituras por meio dessa humilde pesquisa.

A Pontífice Universidade Católica do Rio de Janeiro, por me conceder uma bolsa $100 \%$ filantrópica, e pelo apoio da Reitoria da Puc- Rio para todos os que cursam licenciaturas.

Ao meu professor e orientador Marcos Guedes Veneu pela paciência, generosidade, e por sua nobreza de espírito ter aceitado me orientar desde os meus primeiros semestres no curso de História.

Ao Técnico em Química Sr. Ricardo Correa pelo apoio e incentivo enquanto estive cursando a graduação.

Aos funcionários de Departamento de História da Puc-Rio, professores, meus muitos colegas de graduação dentro e fora do departamento, que ao longo desses anos tanto me ajudaram nos trabalhos e seminários.

Minha família que apesar de não entenderem bem minha caminhada na vida acadêmica, da melhor forma possível, sempre torceram e oraram por mim.

Minha amiga Ana Cristina Pinheiro, seu apoio, compreensão, acolhida e por me ceder seu lar nos bons momentos e nos dias difíceis. 


\section{Resumo}

DINIZ, Ligia C. dos S; A Providência Divina e a História Universal nas visões de Flávio Josefo e Eusébio de Cesareia. Monografia apresentada à Graduação em História da PUC-Rio como requisito parcial para obtenção do título de Licenciatura em História. Rio de Janeiro, 2017.

Esta pesquisa aborda sobre os relatos de dois autores sobre o mesmo evento: as últimas guerras judaicas contra os romanos ocorridas na Palestina entre os anos de 66 E.C com as revoltas dos judeus até 70 E.C com a destruição de Jerusalém e seu templo pelo general romano Tito. O objetivo deste estudo é mostrar como cada autor, Flávio Josefo e Eusébio de Cesareia, abordaram nas suas obras a atuação da providência divina e das profecias e como estas deram rumo aos acontecimentos, envolvendo por fim toda a história universal. Analisando a partir da obra de Josefo A Guerra dos Judeus, escrita no primeiro século, e História Eclesiástica de Eusébio escrita no terceiro século, podemos mostrar como cada um compôs o seu relato usando elementos narrativos que pudessem legitimar seus argumentos; como ambos os autores possuem elementos semelhantes quanto a quem é o responsável pelo destino da humanidade. Apresenta também, a partir do fim da guerra em 70, os diferentes rumos que cada autor deu a respeito do povo judeu. Finalizando com o que cada autor identifica como sendo o povo escolhido por Deus e como estes influenciariam a vida de toda a humanidade. Esta pesquisa contribui para entender como durante muitos séculos os homens procuraram encontrar e dar um sentido para a história, e como até hoje é possível novas pesquisas a partir dos escritos sagrados.

Palavras-chaves: Providência divina; judeus; Flávio Josefo; Eusébio de Cesareia. 


\begin{abstract}
This research deals with the reports of two authors on the same event: the last Jewish wars against the Romans occurred in Palestine between the year of 66 with the revolts of the Jews until the year of 70 with the destruction of Jerusalem and its temple by the Roman general Titus. The purpose of this study is to show how each author, Flavius Josephus and Eusebius of Caesarea, dealt in his works with the work of divine providence and prophecies and how they gave way to events, ultimately involving all of universal history. Analyzing from the work of Josephus The War of Jews, written in the first century, and Eusebius Ecclesiastical History written in the third century, we can show how each composed his account using narrative elements that could legitimize his arguments; as both authors have similar elements as to who is responsible for the destiny of humanity. It also presents, from the end of the war in 70, the different directions that each author gave about the Jewish people. Finishing with what each author identifies as being the people chosen by God and how they would influence the life of all mankind. This research contributes to understand how for many centuries men sought to find and give meaning to history, and how until today is possible new research from the sacred writings.
\end{abstract}

Key words: Divine Providence; Jews; Flavius Josephus; Eusebius of Caesarea. 


\section{Sumário:}

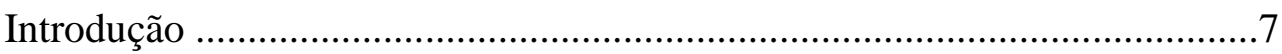

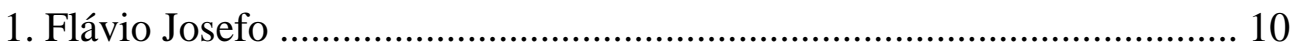

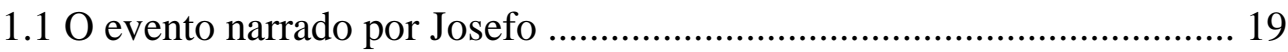

1.2 Josefo, as profecias e a Providência divina ..........................................22

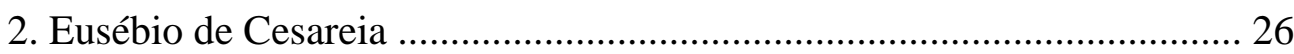

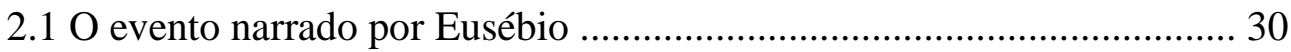

2.2 Eusébio, as profecias e a Providência divina ...................................... 34

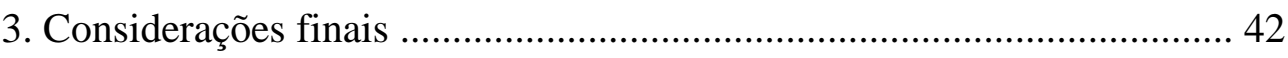

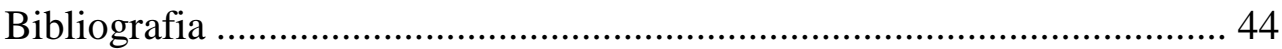




\section{Introdução:}

Um atemorizante, terrível e extraordinário animal surgiu no sonho de Daniel, funcionário do Rei Nabucodonozor, em Babilônia, cerca de seis séculos antes da Era Comum ${ }^{1}$. Este animal tinha grandes dentes de ferro que esmiuçavam e devoravam tudo o que estava pela frente. $\mathrm{O}$ que sobrava esmagava com seus pés. Segundo Professor Florencio Hubeñak ${ }^{2}$, este incrível animal, ao longo de muitas pesquisas historiográficas e teológicas a respeito do livro bíblico de Daniel, vem sendo considerado como a potência política e militar Romana. E apesar dessa concepção teológica não se encaixar no pensamento racional para alguns, serve aqui para introduzir uma metáfora bem apropriada. Esta metáfora é sobre a forma como o Império político Romano, com sua força militar nunca antes vista, foi subjugando um grande número de territórios da Europa. Territórios estes que foram se estendendo desde em torno do Mar Mediterrâneo, das Ilhas Britânicas até chegar a Babilônia.

A primeira destruição do Templo de Jerusalém ocorreu em 607 A.E.C, pelo Rei babilônico Nabucodonosor. Este evento de extrema importância na história do povo judeu será abordado brevemente nesta pesquisa. Aqui trataremos do período específico que abrange apenas quatro anos, 66 E.C-70 E.C, culminando com a segunda destruição do grande Templo de Jerusalém pelo exército Romano. A destruição do segundo templo marcou profundamente a identidade, a cultura e a religião dos judeus. Esta última havia sido atacada de forma direta desde o domínio helenístico, especialmente pela proibição do culto ao seu Deus e dos rituais religiosos reproduzidos pelo povo judeu por centenas de anos.

Segundo Simon e Benoit ${ }^{3}$, os judeus experimentaram, desde o exílio, contato permanente com nações de caráter pagão. Apesar de uma atitude mais fechada e negativa quanto às tradições pagãs, manter a pureza da religião hebreia com tantas

\footnotetext{
${ }^{1}$ Neste texto será usado AEC/EC como sigla que significa "Antes da Era Comum" e "Era Comum", para definir a localização dos determinados eventos na linha do tempo.

${ }^{2}$ Hubeñak, Florencio. "Historia política y profecía: Roma y los grandes imperios antiguos a la luz de las predicciones del profeta Daniel” [en línea]. Hispania Sacra 48, nro. 97 (1996). Disponible en: http://bibliotecadigital.uca.edu.ar/repositorio/contribuciones/historia-politica-profecia-roma.pdf, consultado em 10/10/2017.

${ }^{3}$ SIMON, Marcel; BENOIT, André. Judaísmo e Cristianismo Antigo. De Antíoco Epifâneo a

Constantino. São Paulo. Pioneira; Editora da Universidade de São Paulo, 1987.
} 
influências externas seria impossível. Sob o domínio selêucidas da Síria, e sua política radical de helenização, o conflito com os pagãos evoluiu com a proibição do ato judaico-religioso e a profanação do templo com a introdução do culto a Zeus Olímpico, pelos dominadores gregos. Esta grande ofensa aos judeus deu início à primeira de uma série de revoltas dos judeus, entre os anos 166-160 A.E.C. ${ }^{4}$

Porém o helenismo também contava com adeptos judeus, sobretudo a aristocracia, que passou a "observar costumes pagãos" (SIMON, BENOIT p.52). Renunciar os costumes judaicos monoteístas, em troca dos pagãos significava trocar Jeová (Iahweh) por Zeus Olímpico. Logo se conclui que havia uma opinião judaica dividida, o que permitiu a surgimento de algumas seitas dentro do povo.

Um grupo de rebeldes judeus liderados por Judas, dito macabeu ("martelador") que assumiu a chefia da insurreição, estabelecem uma monarquia independente por 80 anos até serem conquistados pelo General Romano Pompeu, em 63AEC. Logo, não demorou muito tempo para que os judeus agissem de modo hostil contra o novo regime e tentassem sua independência mais uma vez. O que estava envolvido era mais do que o retorno a uma monarquia ou ao território. Era uma questão de identidade da religião milenar dos hebreus. Identificada por si mesmos como o povo escolhido, para ser a raça pura e os plenos representantes do Deus Criador, O Deus dos Deuses, JEOVÁ (Português), יהוה-YHVH (em Hebraico).

Para os judeus, a atuação e os tratos do seu Deus com a nação, haviam sido narrados ao longo da sua própria história, em escritos fidedignos feitos por seus juízes, reis, líderes e profetas. É por essa perspectica que vamos dialogar com dois autores e historiadores: Flávio Josefo e Eusébio de Cesaréia. Ambos escreveram a completa narrativa histórica dos judeus pelo viés que inclui a providência Divina como a causa dos êxitos e das trajédias da nação. Deixando, por assim dizer, o seu Deus Jeová (Javé) e o povo hebreu como protagonistas da maior parte da história mundial. As demais nações e civilizações que tiveram contato com os judeus, incluindo os povos Egípcios, Assírios, Babilônicos, Medo-Persa, Gregos e, por fim, Romanos atuaram como meros coadjuvantes.

\footnotetext{
${ }^{4}$ Conf. SIMON, BENOIT p. 52
} 
Atentando ao período específico já dito, sob o domínio dos Romanos que há algum tempo tentava sufocar as revoltas judaicas, chegamos a 66 E.C. Deste ponto, vamos entender como Josefo, dentro do conflito e se denominando testemunha ocular dos fatos (ora lutando ao lado dos judeus, ora se colocando como observador junto às lideranças Romanas) fez sua versão dos acontecimentos segundo suas interpretações. A partir daí vemos como ele narrou as desgraças dos judeus e o papel punidor de Deus contra seu próprio povo; e o fim da capital e do templo em 70 E.C. Em seguida, analizaremos o relato de Eusébio de Cesaréia, sobre o mesmo período, escrito por ele cerca de dois séculos após a narrativa de Josefo. Ele próprio foi leitor dos escritos de Josefo e responsável por escrever a história da Igreja. Lembrando que ele tentou explicar não apenas a história do povo escolhido e do Messias (ungido, escolhido) vindo deste povo, mas também, como que o ocorrido entre 66 E.C até 70 E.C deu razão e sentido ao nascimento da Igreja Cristã; a vontade de Deus no controle de todos os acontecimentos, em especial após 70 E.C; e a dispersão definitiva dos judeus cristãos pela Terra e sua missão de expandir do Cristianismo.

Dialogaremos com os autores e com seus contextos; seus universos literários; quadros históricos gerais de onde e como viviam; sua época e seus costumes; suas perspectivas quanto à providência, demostradas na forma em como escreveram suas narrativas; o que se pode definir como tendo sido a conclusivo aos seus escritos quanto a história do povo eleito. 


\section{Flávio Josefo}

A respeito do hebreu Flávio Josefo, o historiador François Hartog ${ }^{5}$ comenta que ele viveu entre 37-100 E.C, procedeu de uma família de sacerdotes por parte do pai Jose, e nobres por parte da mãe. Se chamava pelo nome hebraico José ben Matias.

Josefo lutava contra os romanos como importante general na Galileia durante os estágios iniciais da revolta de 67 EC. Estando ele na pequena cidade montanhosa de Jotapata, quando Vespasiano invadiu a Galileia com 60.000 homens para vingar a humilhação sofrida por Céstio Galo, ocorrida em 66 E.C. Os romanos encurralaram os rebeldes judeus num cerco feroz que durou uns 47 dias. Josefo e outros 40 sobreviventes que participaram dessa desastrada campanha, acabaram escondidos dentro de uma caverna. Quando foram descobertos, os romanos ofereceram poupar-lhes a vida, caso eles se rendessem. Josefo foi o único a então se render. Segundo seu próprio relato, diante de Vespasiano, Josefo atribui a vitória romana e a própria posição do rei à determinação de Deus, interpretando uma profecia dos escritos sagrados dos hebreus. Levado sob a guarda dos romanos esteve a princípio como prisioneiro e depois ganhou o favor do imperador romano, ${ }^{6}$ segundo Vicente C. R. A. Dobroruka*.

Josefo gozando de liberdade, justificou sua ascensão social ao lado romano, como providência divina, afim que se fizesse o registro cuidadoso e fidedigno dos fatos. Os judeus como povo "sempre estiveram demasiadamente preocupados com a verdade. O Deus hebreu é um deus da verdade” escreveu Momigliano ${ }^{7}$. Deste modo, tendo uma tradição judia, a respeito da sua obra e de seus pressupostos, Josefo escreveu: "Escrevi todos estes acontecimentos em sete livros para os que amam a

${ }^{5}$ HARTOG, François (org.). A História de Homero a Santo Agostinho. Tradução de Jacyntho Lins Brandão. Belo Horizonte: Ed. UFMG, 2001.

${ }^{6}$ DOBRORUKA, Vicente Carlos Rodrigues Alvarez, Flávio Josefo (34/37d.C.-100d.C.) in: PARADA, Maurício. Os historiadores: clássicos da história. Petropólis, RJ: Vozes; Rio de Janeiro: Ed. PUC-Rio, c2012.

*Doutor em Teologia pela Universidade de Oxford; membro do Ancient India and Iran Trust de Cambridge; professor-visitante em Clare Hall, Cambridge; professor da universidade de Brasília (UnB).

${ }^{7}$ MOMIGLIANO, Arnaldo. As Raízes Clássicas da Historiografia Moderna. Trad. Maria Beatriz Borba Florenzano. EDUSC, Bauru. São Paulo, 2004. P.28 
verdade, não por prazer. Eu o fiz sem dar motivo, aos que conhecem os feitos e estiveram presentes na guerra, para que me acusem ou critiquem". ${ }^{8}$

Por conta de sua adoção com o imperador Vespasiano, recebeu o nome latino Titus Flavius Josephus. Foi o autor de A Guerra dos Judeus ${ }^{9}$, As Antiguidades Judaicas ${ }^{10}$, uma autobiografia $A$ vida de Josefo ${ }^{11}$ e Contra Ápio ${ }^{12}$. Ele defendeu a excelência e a antiguidade dos hebreus, em detrimento do comportamento dos judeus da sua época, que ele próprio chamou de hipócritas, assassinos e bandidos. Se tornou um cidadão romano até morrer por volta do II século E.C.

Apesar de Josefo ter redigido seu texto para o público letrado pagão, explicando o universo judaico e sua própria trajetória pessoal, ele não alcançou este objetivo. Seus escritos foram preservados pelos primitivos judeus cristãos. Veremos mais a frente como os cristãos fizeram uso dos escritos de Josefo, como, por exemplo na obra sobre a história da igreja de Eusébio, bispo de Cesareia no III século E.C.

O historiador Josefo inicia seu percurso como tal, com a narrativa dos acontecimento ligados à guerra de 70 E.C. A partir deste, estendeu-se a uma análise de toda a história tendo como fio condutor o povo hebreu e a relação com seu Deus. Aqui predendemos entender sua concepção de história universal e da providência divina no rumo dos acontecimentos.

Tomando como princípio que o povo hebreu foi o mais injustiçado por parte dos 'historiadores ilustres' de lingua grega, Josefo 'fez uma relação com os acontecimentos envolvidos na última guerra judaica contra os romanos em 70 E.C, com a narrativa da história dos judeus, retrocedendo até a criação do mundo'. ${ }^{13}$

\footnotetext{
${ }^{8}$ JOSEFO, Flavio. A Guerra dos Judeus II. Tradução e adaptação de A.C.Godoy. Curitiba, Ed. Juruá, 2002. P. 14

${ }^{9}$ JOSEPHOS, Flavius. The War of Jews. Books I-VII. William Whiston, A.M., ed. http://www.perseus.tufts.edu/hopper/text?doc=Perseus\%3atext\%3a1999.01.0148, consultado em $11 / 10 / 2017$.

${ }^{10}$ JOSEPHOS, Flavius.THE ANTIQUITIES OF THE JEWS Books I-XX. Translated by William Whiston.

http://www.gutenberg.org/files/2848/2848-h/2848-h.htm, consultado em 12/10/2017.

${ }^{11}$ JOSEPHOS, Flavius. Life of Josephus. Translated by William

Whiston.http://data.perseus.org/catalog/urn:cts:greekLit:tlg0526, consultado em 12/10/2017.

12 JOSEPHOS, Flavius. Against Apion.Translated by William.

Whiston.http://data.perseus.org/catalog/urn:cts:greekLit:tlg0526, consultado em 12/10/2017.

${ }^{13}$ DROBORUKA, p. 108
} 
A história dos judeus, segundo Josefo, mostra ser um tipo peculiar de história universal, pelo fato de ser a história de um povo escolhido e "principiar com a criação do mundo e ligar-se cada vez mais intimamente aos eventos ocorridos no resto do mundo após o exílio do povo hebreu". ${ }^{14}$

O método usado por Josefo para sua narrativa seguiu alguns padrões da antiguidade Tucidiana. Deste modo, ele buscou as causas da verdade da história por meio da autópsia, ou seja, do seu próprio testemunho ocular e do testemunho dos que participaram dos acontecimentos: como Vespasiano, Tito e outros que participaram da guerra contra os rebeldes judeus. A diferença entre a obra de Tucídides e Josefo está em como concebem a essência dos eventos e como procederam. Para Tucídides o problema estava ligado a falência do corpo político da nação, nada tinha haver com religião. Para Josefo a decadência do povo hebreu, a sua apostasia, e as consequentes desgraças, eram prova não de má gestão, e sim da punição de seu próprio Deus por causa dos seus pecados contra a Lei. ${ }^{15}$

De acordo com Josefo, sua história seria fidedigna, porque entre os historiadores gregos 'a ausência de registros oficiais os levavam a graves erros e a possíveis mentiras para os que depois desejassem consultar e escrever sobre as antiguidades' ${ }^{16}$ Aliás, sobre a antiguidade, Josefo chega a escrever que apenas 'os profetas conheceram o mais antigo', já que a 'inspiração divina' lhes deu a capacidade de saber o mais remoto dos acontecimentos, mesmos que esses não tenham sido presenciados. Além de poderem com toda a autoridade escrever de modo claro o que aconteceu na sua própria época, no seio de seu próprio povo. Os 'escritos dos profetas não se contradizem nem discordam entre si' ${ }^{\prime}$. Todo judeu crê que esses escritos são sagrados e crê que 'são os decretos de Deus' ${ }^{\text {' }}$. Estando eles dispostos a até suportar tortura, todo sofrimento e a própria morte do que negá-los.

Josefo não foi o primeiro historiador a propôr ser autobiográfico, mas segundo Dobruruka, em Os Historiadores, "Josefo foi o primeiro a nos legar uma obra

\footnotetext{
${ }^{14}$ DROBORUKA, p.108

${ }^{15}$ DROBORUKA, p. 109

${ }^{16}$ JOSEFO, Contra Ápio (v.15), in: HARTOG, François (org). De Homero a Santo

Agostinho.Editora UFMG, Belo Horizonte.2001.

${ }^{17}$ Idem

18 Idem
} 
completa que tem por tema a própria vida de quem escreve". ${ }^{19}$ Nas suas obras, Josefo mostra ser profundo conhecedor das práticas de seu povo, dos seus escritos e dos seus escritores, dedicando-se a um grande empreendimento ao produzir Antiguidades Judaicas (entre 93-94 EC), obra reconhecida pela sua grande importância aos estudos sobre as antiguidades.

Entre esses estudos, aqui se faz importante entender que dentro do judaísmo era possível haver interpretações diversas, igualmente legítimas desde que acatassem os princípios fundamentais da fé, e da lei. O que contribuiu para o surgimento de grandes seitas judaicas, que coexistiam com conflitos constantes, sem que uma conseguisse eliminar a outra. Entender como se deu as revoltas dos judeus irá nos ajudar a entender o surgimento dessas facções.

Segundo Arnaldo Momigliano ${ }^{20}$, as revoltas dos judeus começaram na Palestina quando os selêucidas da Síria dominavam. Na mesma época já existiam conflitos internos entre o povo judeu. Por não compreenção por parte de Antíoco IV Epifânio, então rei, da distinta posição monoteísta dos judeus em comparação a outros povos dominados, e querendo ampliar a helenização de seus súditos, ele estabeleceu uma política ofensiva para os judeus. Esta incluia transformar o templo de Javé em templo para o deus Zeus Olímpico; o saque dos utensílios sagrados do templo para usos pagãos; a interrupção das práticas tradicionais como a circuncisão e a observação do dia de sábado. Foi uma grande interferência nos cultos ancestrais de uma nação desde os tempos imemoriais ${ }^{21}$.

Porém, a política de Antíoco ganhou um terreno fértil, pois entre o povo judeu o helenismo ganhou numerosos adeptos, em especial a aristocracia, que se apressaram em procurar o rei, que lhes deu permissão para observar os costumes pagãos, renegando sua aliança com a Lei de Iahweh e se juntaram aos pagãos. ${ }^{22}$ Por parte dos judeus fervorosos a única reação a esta ação ofensiva, seria uma guerra santa.

\footnotetext{
${ }^{19}$ DOBRORUKA, p. 107

${ }^{20}$ MOMIGLIANO, Arnaldo. Os limites da helenização. Trad. Claudia Martinelli Gama, Jorge

Zahar Editora, Rio de Janeiro, RJ, 1991, p.91

${ }^{21}$ Idem

${ }^{22}$ Idem 3
} 
Um grupo denominado de piedosos (hasidim) se levantou com um fervor religioso e orgulho nacional junto com a massa popular, contra os judeus helenizados. Um judeu, Judas Macabeu, duma família conhecida como os asmoneus, surgiu como líder. Os asmoneus eram da descendencia de Asmon, da antiga dinastia real e sacerdotal dos hebreus. Asmon teve um filho também sacerdote chamado Matatias, 'que deu início em 167 A.E.C., na cidade de Modim a primeira rebelião. Foi morto, e seu filho chamado Judas, o Macabeu (significado seja "martelador"), assumiu a chefia da rebelião. Depois de sua morte, seus irmãos Jonatã e Simão deram continuidade à dinastia dos asmoneus (derivado de seu avô), que conseguiram manterem-se no poder uns 100 anos, pois haviam feito acordos com os gregos. Sob os últimos asmoneus, sumo sacerdotes e patriarcas, a Palestina foi um Estado vassalo'.

Cerca de três anos e meio depois do início da revolta, a luta pela continuidade de sua religião se tornou uma nova luta pela independência. Isso reafirmaria a fidelidade da comunidade judia ao Deus de Abraão, Isaque e Jacó ${ }^{23}$, seus ancestrais ilustres. Os governantes selêucidas se opuseram fortemente aos macabeus. Contudo, com o tempo, os governantes aceitaram fazer um acordo político, concedendo-os certo grau de autonomia. Abaixo veremos com mais detalhes que trata do confronto que deu origem as seitas judaicas.

Nem todos judeus se agradaram de que os asmoneus usurpassem tanto o controle religioso como o político. Simon e Benoit escrevem que a casta sacerdotal se aproximou dos pagãos antes gregos, agora romanos e conservava privilégios e prestígio, tendo o cargo de sumo-sacerdote perdido o caráter hereditário desde o fim dos asmoneus, e sendo a nomeação agora concedida pelos romanos. ${ }^{24} \mathrm{Ou}$ seja, a nomeação dos cargos religiosos judeus estavam sendo feito pelos pagãos. Foi durante este período que se acentuou a rivalidade entre sacerdotes e os doutores da Lei, os escribas.

Desde o exílio, a instituição das sinagogas correspondia aos judeus da diáspora a necessidade de se reunirem para prática do seu culto. Com a proibição de se oferecer sacrifícios nas regiões fora de Jerusalém, as atividades na sinagoga eram espirituais.

\footnotetext{
${ }^{23}$ MOMIGLIANO, Limites da Helenização, p. 92.
}

${ }^{24}$ SIMON e BENOIT, p.56. 
Representava o lugar para o ensino, leitura, meditação do Livro sagrado. Como não havia secerdotes, os sábios, rabinos versados na Lei, tinham que comunicar às ovelhas a essência dos livros. ${ }^{25}$ A tensão entre os sacerdotes e os saduceus tornouse para Josefo as duas primeiras representações do judaísmo.

Os saduceus, nome que derivaram do antigo sacerdote de Salomão, Sadoque, provinham da aristocracia sacerdotal. No entanto, nem todos os saduceus eram desta linhagem. Os saduceus eram os aristocratas e os ricos da nação, e não tinham o apoio das massas. Eles tiveram por muito tempo um relacionamento com os poderosos. Eram integrantes da alta administração e eram zelosos observadores da Lei. Eles eram extremistas quanto a manutenção da ordem pública, mesmo que esta fosse a base das normas romanas. Tinham pouca sensibilidade quanto à mensagem dos profetas e ao posterior messianismo em Jesus.

Sobre os saduceus escreveu Josefo:

"Os saduceus negavam os caprichos do destino, sustentando que a própria pessoa, pelas suas ações, era a única responsável pelo que lhe sobrevinha. Rejeitavam as muitas tradições orais observadas pelos fariseus e também a crença farisaica na imortalidade da alma e em punições ou recompensas após a morte e a ressurreição. Nos seus tratos entre si, os saduceus eram um tanto rígidos". ${ }^{26}$

Em oposição frontal aos saduceus, estavam os fariseus, do hebraico perushim, separados, talvez porque os fariseus evitavam impurezas cerimoniais e mantinhamse separados dos gentios e pagãos. Acentuavam a separação entre o povo eleito (eles) e os pagãos impuros. Os fariseus eram eruditos tirados dentre o povo comum, e desenvolveram uma nova forma de leitura interpretativa das Escrituras, e um conceito posteriormente conhecido como a lei oral. Em matéria de crença, os fariseus professavam certas ideias que tinham escasso ou nenhum apoio nas

\footnotetext{
${ }^{25}$ SIMON e BENOIT, p.57.

${ }^{26}$ JOSEFO, Flávio. Jewish Antiquities, XIII, 288; http://www.perseus.tufts.edu/hopper/text?doc=Perseus\%3Atext\%3A1999.01.0146\%3Abook\%3D1 3\%3Asection\%3D288; A Guerra dos Judeus, Livro II, 162-166.
} 
Escrituras, pregavam a angelologia, doutrinas impregnadas de influências estrageiras, segundo Simon e Benoit. ${ }^{27}$

Ao que tudo indica, seus ancestrais devem ser procurados entre os hasidim, da rebelião dos macabeus. Pequeno grupo minonitário quando do seu surgimento, os fariseus aos poucos foram estendendo sua influência sobre toda vida religiosa de Israel dentro e fora da Palestina. Após o ocorrido em 70, o farisaísmo e judaísmo se tornaram sinônimos: o judaísmo deve sua sobrevivência aos fariseus. ${ }^{28}$

Os escritos de Josefo indicam que no tempo de João Hircano I (da segunda metade do segundo século AEC) os fariseus já constituíam um corpo influente. Josefo escreveu que sua influência é tão grande junto às massas, que até mesmo quando falam contra um rei ou um sumo sacerdote, imediatamente são cridos. ${ }^{29}$ Josefo também menciona as bases da crenças dos fariseus.

Ele observa:

\begin{abstract}
"Eles crêem que almas têm poder de sobreviver à morte e que há recompensas e punições debaixo da terra para os que levaram uma vida de virtude ou uma de vício: encarceramento eterno é o destino das almas más, ao passo que as almas boas recebem passagem fácil para uma nova vida... eles sustentam que toda alma é imperecível, mas que só a alma dos bons passa para outro corpo, ao passo que a alma dos iníquos sofre punição eterna". ${ }^{30}$
\end{abstract}

Sobre as idéias deles a respeito do destino ou da providência, Josefo relata: "[Eles] atribuem tudo ao Destino e a Deus; acreditam que agir corretamente ou de outro modo depende, na realidade, na maior parte dos homens, mas que em cada ação o destino coopera". ${ }^{31}$ Criam particularmente na ressurreição apenas dos homens justos.

\footnotetext{
${ }^{27}$ SIMON e BENOIT, p.61.

${ }^{28}$ SIMON e BENOIT, p.60.

${ }^{29}$ Jewish Antiquities Livro XIII, cap. 10 v. 5, http://www.gutenberg.org/files/2848/2848-h/2848h.htm\#link132H_4_0001. Consultado em 27/10/2017.

${ }^{30}$ Jewish Antiquities, XVIII, Cap.1, v. 3. http://www.gutenberg.org/files/2848/2848-h/2848h.htm\#link182H_4_0001. Consultado em 27/10/2017.

${ }^{31}$ JOSEFO, Flávio. A Guerra dos Judeus, Livro II, 162, 163.
} 
Os essênios representavam uma forma bastante original de judaísmo. 'Admite-se em geral que a origem da sua seita se vincula à insurreição dos macabeus. È possível que ver nos hasidim os antepassados tanto dos fariseus quanto dos assênios. Provavelmente, o núcleo primitivo da seita dos essênios foi constituído por famílias sacerdotais que se colocaram em oposição, quando a dinastia dos asmoneus ao associar o pontificado supremo à realeza, tornaram-no hereditário. Foram hostilizados por esta atitude. Tiveram vozes entre as facções judaicas, apesar de viverem nas margens das agitaçoes religiosas fora de Jerusalém. De forma voluntária se estabeleceram nas margens do Mar Morto, em pleno deserto do Qunram. Tiveram um líder mencionado no Qumran, o mestre da justiça, que desempenhou um papel capital na organização da seita, cuja a identidade ficou no anonimato, e tenha sido morto como mártir perseguido pelo sacerdócio de Jerusalém'. ${ }^{32}$

O essênios tinham uma orgulhosa convicção de que eram os verdadeiros descendentes do Israel antigo, o pequeno grupo de eleitos, que não se poluiram espiritualmente com a adoração do imperador nem com os sacrifícios a Zeus.

Simon e Benoit, citam os documentos de Qumran com dados importantes sobre as crenças dos essênios. Fragmentos de livros canônicos do Antigo testamento, pseudo-epígrafos, hinos, manual de disciplina e livro de guerras. Eles viviam à espera do final dos tempos. Estavam convencidos de serem o "resto" de Israel e prontos para travar o combate supremo com as hordas de Satã (SIMON e BENOIT, 1991, p. 64).

Afastando-se dos fariseus e saduceus, destacamos o grupo mais próximo de um tipo de nacionalismo judaico radical; os zelotes. Os zelotes surgiram com o líder Judas, o Galileu, que fomentou uma insurreição, logo reprimida, em 6-7 E.C., quando se estabelecia a Judéia como província romana. Os zelotes se recusavam a reconhecer autoridade humana, uma anarquia radical cuja a defesa da teocracia significava a plena eliminação dos ocupantes pagãos. Eliminação esta por meio da violência. Eram os mais virulentos, e foram responsáveis vários incidentes e agitações. ${ }^{33}$

\footnotetext{
${ }^{32}$ Conf. SIMON e BENOIT, p. 63.

33 JOSEFO, Flávio. A Guerra dos Judeus, Livro II, 162, 163 (viii,14).
} 
Josefo diz ter sido eles os maiores responsáveis pela revolta de 66 E.C, e as desgraças e calamidades contra todo povo judeu em 70E.C.

Sobre eles Josefo escreveu:

"Mas da quarta seita da filosofia judaica, Judas Galileu foi o autor. Esses homens concordam em todas as outras coisas com as noções farisaicas; mas eles têm um apego inviolável à liberdade, e dizem que Deus deve ser o único governante e Senhor. Eles também não valorizam a morte de qualquer tipo, e nenhum temor quanto a morte pode fazê-los chamar qualquer homem de senhor..."

Definidos os quatro grupos, terminamos dizendo que por razões já explicadas, a aristocracia dos judeus, os fariseus e os saduceus, que se aproximaram aos romanos, cederam a pressão. Estas seitas já se enfrentavam para ganhar o apoio popular e influenciar o povo para o lado deles. A crise de 70 E.C., fez com que os fariseus se destacassem e saíssem vitoriosos com a eliminação dos seus rivais pelas hostes romanas.

Para nós aqui, o que de fato importa é o cerco de Céstio Galo em 66 E.C e o estágio inicial da última grande revolta dos judeus a partir de 67 E.C, até culminar com a destruição do segundo templo de Jerusalém em 70. Nos importa porque os escritos de Josefo seriam usados por outros historiadores, e também nos aproximará da conclusão da profecia a respeito da punição a apostasia judaica, pelas mãos justas do Deus de Israel.

${ }^{34}$ JOSEFO. Jewish Antiquities, XVIII, cap. 1 v. 6, http://www.gutenberg.org/files/2848/2848h/2848-h.htm\#link182H_ 4 0001. Consultado em 27/10/2017. 


\title{
1.10 evento narrado por Josefo
}

Ao narrar a campanha e o cerco de Céstio Galo contra as cidades da Galiléia, de Tiro, da Cesaréia e ao templo sagrado pelos hebreus em Jerusalém, Josefo em Guerras dos Judeus diz que Céstio, sabendo que os judeus haviam sido atacados pelos gregos, percebeu que era o momento de tomar uma ação. Assim reuniu soldados, tropas e forças auxiliares de outras cidades que odiavam os judeus. Atacou por terra e por mar, subjugando, matando, pilhando e incendiando as regiões por onde seu exército passava. Cestio Galo e seu exército encontraram alguma resistência dos judeus, que chegaram a matar alguns dos seus soldados, mas sucumbiram e fugiram para uns montes e se esconderam em lugares de difícil acesso .

Assim, narra Josefo:

\begin{abstract}
"As tropas romanas entraram no bairro chamado Delta, onde estava concentrada a população judia, e cumpriu, não sem derramamento de sangue, o que lhes havia ordenado. Os judeus conseguiram resistir durante bastante tempo, pois haviam se agrupado e tinham colocado na vanguarda seus melhores homens armados. Mas enquanto retrocediam foram totalmente massacrados". (v. 493) 35
\end{abstract}

Depois também de continuar reunindo soldados, tropas e forças auxiliares de outras cidades que odiavam os judeus, o exército romano atacou por terra e por mar, matando e incendiando as regiões por onde seu exército passava. Céstio Galo e seu exército encontraram alguma resistência dos judeus, que chegaram a matar alguns dos seus soldados, mas sucumbiram e fugiram para os montes e se esconderam em lugares de difícil acesso.

Céstio Galo segue marchando em direção a Jerusalém. Visto que era época das festas dos tabernáculos, muitos judeus estavam fora da cidade. Contudo, 'quando

35 JOSEFO, Flávio. A Guerra dos Judeus, Livro II. Tradução e Adaptação de A.C. Godoy. Juruá, 2009. 
souberam que as tropas se acercavam da capital, logo se esqueceram dos seus costumes quanto a guardar o sábado de nenhum tipo labuta. Uns pegaram suas armas e partiram para cima dos romanos, outros se esconderam no interior da cidade. Os valentes desbarataram uma linha de batalha romana atrás da outra, e nesse ímpeto ardor de coragem, conseguiram uma grande matança's6

Depois, os rebeldes perseguiram as tropas romanas pelas planícies, fora da cidade, e atacaram guarnições traseiras e pilharam seus pertences de guerra para usar contra eles mesmos. Porém, num momento de discórdia internas entre os judeus, Céstio viu a oportunidade de atacá-los. Sua estratégia foi bem sucessida. Com o treinamento e a disciplina dos exércitos romanos ao seu favor, deu ordem de avançar e cercar as muralhas da cidade, estando nesse ponto prestes a se apoderar e dar fim a guerra. Todavia, aconselhado por seus comandantes, não o fez. Estendendo as desgraças dentro da cidade, com disputas cada vez piores entre os que queriam e os que não queriam o conflito.

Josefo escreveu:

\begin{abstract}
"Entao Agripa, ao ver que os romanos corriam perigo por causa da quantidade de inimigos que rodeavam as mantanhas, considerou conveniente negociar com os judeus para convencelos de que abandonassem a guerra ou para apartar do grupo de adversários os que não estivessem de acordo com eles. Enviou e eles seus amigos, Borcio e Febo muito conhecidos pelos judeus, com a promessa de que Céstio faria um tratado com eles e de que com segurança os romanos lhes perdoariam as faltas, se depusessem suas armas. Mas os rebeldes que temiam que toda a multidão se colocasse do lado de Agripa com a esperança de anistia, se precipitaram contra estes embaixadores do rei e os assassinaram".37
\end{abstract}

Quando o povo protestou contra essa ação dos rebeldes, foram golpeados com paus e pedras e empurrados para o interior da cidade. Josefo conta que o prefeito do

\footnotetext{
${ }^{36}$ JOSEFO, L.II v. 511-516.

${ }^{37}$ JOSEFO, L.II, v. 521-523.
} 
acampamento dos romanos e a maioria dos comandantes da cavalaria, receberam suborno para fizerem Céstio desistir de se apoderar da cidade.

À medida que o exército romano se protegia e minava a muralha, prestes a atear fogo na porta do templo, o desespero tomava conta dos judeus rebeldes os quais começaram a fugir da cidade. Os outros que não queriam a guerra, já estavam prestes a abrir a porta para receber Galo como benfeitor (L.II v.535-536).

Essa passagem é de suma importância para entendermos a interpretação de Josefo. Ele escreveu:

\footnotetext{
"Mas creio que Deus, do lado dos criminosos, havia se apartado desta cidade sagrada e por isto impediu que a guerra acabasse naquele dia. Céstio, sem se dar conta do desespero dos sitiados nem da atitude favorável do povo, chamou de repente seus soldados, renunciou às esperanças e levantou o acampamento da cidade, sem nenhum tipo de razão e sem haver sofrido nenhum tipo de derrota”. (L.II,v.537-538)
}

Durante a retirada, o exército romano ainda sofre um ataque na retaguarda. Houve algumas baixas entre os romanos e pilhagem dos seus equipamento. Isso faz os judeus rebeldes se encherem de confiança e passarem a convocar, muitas vezes à força, recrutas para armarem uma defesa de Jerusalém. Em toda cidade "forjavamse flechas e armaduras; grupos de jovens se dedicavam à instrução militar sem nenhuma ordem e em todos os lugares reinava o tumulto". Parecia que nem todos estavam otimistas com as perspectivas. Havia uma nuvem de presságios, ou, muitas espectativas de desgraças sobre Jerusalém. Jerusalém era uma cidade prestes a sofrer uma destruição.

A intervenção Divina não permitiu que Céstio se apoderasse da cidade, pois bastava insistir só mais um pouco para derrotá-los. Aliás, ele não sabia do desespero nem da atitude de rendição de alguns do povo. Sem razão e sem ter sofrido nenhuma derrota, chama de repente seus soldados, levanta acampamento e se retira do combate. Aliás, para Josefo, Céstio foi usado por Deus como instrumento para continuar a punição ao povo infiel. Sem razão estratégica militar, sem razão lógica, 
do ponto de vista humano, uma ação que não se explicava para um comandante experiênte com um exército treinado. A intervenção Divina não permitiu que Céstio se apoderasse da cidade. Ponto este que veremos a seguir. 


\subsection{Josefo, as profecias e a providência divina}

Profundo conhecedor da história de seu povo, por inúmeras vezes Josefo cita a vontade e a providência de Deus no controle dos acontecimentos. Aqui encontramos o ponto principal: Josefo tinha conhecimento de que em muitas ocasiões o povo hebreu foi salvo por seu Deus em batalhas em que não precisaram nem mesmo levantar uma espada para lutar. Ele entendia também que muitas vezes seus antepassados, devido suas ações de infidelidade espiritual foram punidos. Neste evento, no qual narra as desgraças do povo e do templo em Jerusalém, não seria diferente. Ele faz sua interpretação geral, uma meta-história que dá o pleno sentido do que se escreve. Ou seja, os tratos do Deus Jeová com seu povo escolhido Israel.

O já citado autor Vicente Dobroruka, enumera quatro linhas para essa interpretação: “1) O sentido da história humana é dado por Deus; 2) Esse sentido é apreensível pelos profetas, em cuja tradição hermenêutica Josefo pretende aparentemente se inserir; 3) A interpretação errônea dos sinais dados por Deus quanto ao sentido da história leva a desatres como e de 70; 4) Como Senhor da história, Deus tem o poder de deslocar o foco de seu favor dos judeus para outros povos, como de fato ocorreu com relação aos romanos, segundo Josefo".38

Não fica difícil entender porque os judeus estavam sendo punidos e os romanos estavam numa posição de potência mundial em ascensão. A rebelião e a sedição do povo era o conceito-chave da obra de Josefo ao relatar os pecados dos judeus e seu fim desatroso. O conceito de stasis (confronto, oposição) compôs o pior dos erros entre os judeus, ou seja, o conflito provocado pelas dissenções civis levaram os rebeldes a cometer as atrocidades contra seus inimigos; além da profanação do templo com o derramamento de sangue de seus opositores dentro dos recintos sagrados. Sobre este último crime, os "falsos profetas", denunciados com vigor por Josefo, tiveram sua participação ao anunciar falsos sinais em troca de suborno, atraindo com este sinal os opositores dos tiranos, segundo Josefo (líderes rebeldes)

${ }^{38}$ DOBRORUKA. 2012, p.112 
para dentro do templo, com a falsa expectativa de salvação, para alí serem destruídos ${ }^{39}$.

O conceito cristão de heresia não se aplica nos escritos de Josefo. Para ele heresia significava apenas "escolha, opção, escola filosófica ou religiosa". ${ }^{40}$ A questão estava bem próxima do padrão pecado-punição-perdão presentes na história dos hebreus.

Como já vimos as quatro seitas judaicas eram: os fariseus, os saduceus, os zelotes, e os essênios. Estas 'eram demostrações das várias interpretações de um povo que, há muito tempo não tinha uma autoridade que pudesse impor a todos em geral, apenas um ponto de vista'. ${ }^{41}$ Característica interpretada por Josefo como sinal de desaprovação de Deus, diante de seus erros.

A ênfase na conduta e o monoteísmo, segundo Simon e Benoit ${ }^{42}$, eram fundamentais para os hebreus. Se por um lado seu dogma se resumia à unidade de Deus e a escolha de Israel como povo eleito, em comparação a sua apostasia e seu desvio das práticas sagradas da Lei que os separavam dos demais povos, eram muito graves. Esse Deus único, criador pessoal e todo-poderoso era também um Deus de misericórdia, mas não insentava seu povo das devidas punições. Amá-lo e temê-lo era o princípio fundamental. Ser judeu significava obedecê-lo em todos os aspectos da vida privada e pública. ${ }^{43}$

Todas as seitas tinham a fé no Deus e a prática na mesma observância, junta a esperança que seu Deus não os deixaria para sempre nas mãos de inimigos. Mesmo não havendo, desde a primeira destruição do templo pelos babilônicos um rei ungido por um profeta verdadeiro que representasse a autoridade de Jeová Deus na terra, mais cedo ou não Deus iria manifestar seu poder a favor do seu povo. Para Josefo isso era claro, ele só não deu conta de explicar como se daria, e como seria o restabelecimento da nação após interpretar a clara evidência do desfavor divino em 70 E.C. Para Josefo a esperança na providência deuteronômica estava baseada

\footnotetext{
${ }^{39}$ DOBRORUKA, p. 115.

${ }^{40}$ SIMON e BENOIT, p. 60.

${ }^{41}$ SIMON e BENOIT, p. 59.

${ }^{42}$ SIMON e BENOIT, p.55.

${ }^{43}$ SIMON e BENOIT, p.56.
} 
na interpretação do ocorrido no pós-exílio de Babilônia. Era o momento de aceitar a realidade e esperar a providência.

Josefo cita em A Guerra dos Judeus a posição que Roma assumiu como potência político militar, seguindo a linha revelatória dos livros sagrados. Os escritos diziam que surgiria no tempo devido um imperador na terra dos judeus (Vespasiano), e este traria a destruição ${ }^{44}$. Aqui ele cita o livro de Daniel 9:26,27 que diz:

“... E o povo de um líder que virá destruirá a cidade e o lugar santo. E o seu fim será pela inundação. Até o fim haverá guerra; o que foi determinado são desolações... E aquele que causa desolação virá na asa de coisas repugnantes; e o que foi determinado será derramado também sobre aquele que é desolado, até a exterminação." ${ }^{45}$

Josefo reconhecia o livro de Daniel como sagrado, porque considerava-o como um profeta do séc.VI A.E.C. E foram estes versículos que ele apresentou a Vespasiano por ocasião de sua captura em Jotapata. O conceito de história tinha um sentido determinado por Deus, manobrando todos os fatos e deslocando a fortuna para os romanos a fim de impor a derrota aos judeus. Tudo era, sim, por parte da providência divina. Vicente Dobroruka argumenta que 'Josefo se põe a luz da imitação dos personagens e profetas bíblicos, como e o próprio Daniel ao se portar como intérprete das visões'. ${ }^{46}$

Por fim, Josefo narrou este importante episódio da história dos judeus, logo história universal, considerando Roma como potêncial mundial pela vontade do Deus criador e Deus dos judeus. A imitação dos profetas antigos colocou Josefo e sua narrativa sobre o cerco de Céstio em 66 E.C e a destuição de Jerusalém por Tito em 70 E.C, no padrão dos antigos textos bíblicos sobre os vários desvios do povo judeu.

44 Conf. JOSEFO, Guerras Judaicas, L.6 310-315.

${ }^{45}$ Tradução do Novo Mundo da Bíblia Sagrada. ASSOCIAÇÃO TORRE DE VIGIA DE BÍBLIAS E TRATADO, BRASIL, 2016.

${ }^{46}$ Idem nota 13 p. 118 
Após escrever A Guerra dos Judeus, Flávio Josefo passando em seguida a escrever as Antiguidades Judaicas, ele reafirmaria nao só sua confiança na providência divina regendo o rumo dos acontecimentos, mas, a sua interpretação da centralidade dos destinos, dados por ela, ao povo judaico dentro da história universal. 


\section{2 - Eusébio de Cesareia}

Segundo a Grande Enciclopédia Barsa ${ }^{47}$, Eusébio de Cesareia, ou Eusébio Panfílio, possivelmente nasceu no ano de $265 \mathrm{EC}$. Estudou na importante escola de teologia criada por Pânfilo, e por volta de 313 EC tornou-se bispo da cidade de Cesareia na Palestina. Eusébio se destacou na história por ser considerando o pai da historiografia cristã.

Eusébio viveu uns 80 anos (c. 260-c. 340 EC), tornando-se um dos escritores mais produtivos da antiguidade. Seus escritos abrangem os acontecimentos dos primeiros três séculos até o tempo do Imperador Constantino. Na última parte da sua vida, seu trabalho como escritor estava conjugado com as suas atividades como bispo. Embora seja mais conhecido como historiador, Eusébio também era apologista, topógrafo, pregador, crítico e escritor exegético. Morre por volta de 340 E.C.

Segundo François Hartog "o primeiro historiador cristão no pleno sentido" ${ }^{48}$. Procurava conciliar a teologia oficial da Igreja com a considerada heresia ariana. Inclusive ele foi ameaçado de excomunhão da Igreja, até se defender no Concílio de Nicéia, convocado pelo próprio Imperador Constantino o qual suspendeu sua punição após sua defesa.

Além da história da igreja, Eusébio escreveu uma Crônica em dois volumes. O gênero das crônicas é uma narrativa histórica que expõe os fatos seguindo uma ordem cronológica. Ele descreveu os eventos relatados de acordo com a sua própria visão crítica dos fatos. O primeiro volume das crônicas de Eusébio é um resumo da história universal. Pretendia ser um compêndio de história organizada segundo as diversas nações, recorrendo às fontes históricas que Eusébio pesquisou arduamente. No quarto século, este tornou-se o texto padrão de consulta sobre a cronologia do mundo. O segundo volume cita datas de acontecimentos históricos. Usando um estilo de escrita paralela com uso de quadros, estabeleceu um sincronismo com o

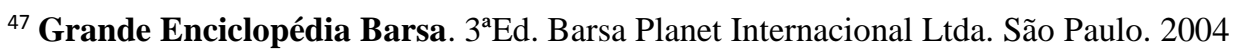

${ }^{48}$ HARTOG, François. A História de Homero a Santo Agostinho. Trad. Jacynto Lins Brandão. Ed. UFMG, Belo Horizonte, MG. 2001, p. 257.
} 
material histórico que possuía. Assim, Eusébio alista a sucessão de reis de diversas nações.

François Hartog escreve que a grande importância dessa obra "está na inserção dos cristãos na história universal, precisamente através da cronologia" ${ }^{49}$. Por meio da linhagem dinástica presente nas informações sobre as potências mundiais e suas sucessoras, ele compõe histórias separadas de conexões. Uma após outra cronografia, sua história foi se afunilando até restar somente o império romano em paralelo com os tempos dos cristãos, nação que Hartog chama de ao mesmo tempo 'nova e velha' ${ }^{50}$. Nova porque surgiu a partir de Cristo e os apóstolos; e velha devido à eleição divina como povo escolhido desde o início da formação do mundo. Eusébio escreveu mais duas obras históricas, intituladas Mártires da Palestina e Vida de Constantino. A primeira obra abrange os anos 303 AEC-10 E.C e considera os mártires daquele período. Eusébio teria sido testemunha ocular desses acontecimentos. A obra posterior (publicada como uma série de quatro livros, após o falecimento do Imperador Constantino em 337 E.C) contém valiosos pormenores históricos. Em vez de ser história biográfica como a imaginamos hoje, seus escritos possuem um caráter monumental. Um gênero biográfico de exaltação a vida de grandes homens fiéis e dignos de honras, conhecido como elogios.

As obras apologéticas de Eusébio incluem uma resposta a Hiérocles — um contemporâneo governador romano. Quando Hiérocles escreveu contra os cristãos, Eusébio respondeu em defesa deles. Além disso, em apoio da autoria divina das Escrituras, ele escreveu 35 livros chamados Praeparatio Evangelica (15 livros) e Demonstratio Evangelica (20 livros) considerados como o esforço mais importante e elaborado desse tipo tentando provar a excelência do cristianismo sobre todas as religiões e filosofias pagãs. Os primeiros 15 deles procuram justificar a aceitação dos escritos sagrados dos hebreus pelos cristãos. Os outros 20 fornecem provas de que os cristãos têm razão para ir além dos preceitos judaicos e adotar novos princípios e práticas. Esses livros, juntos, apresentam uma defesa compreensiva do cristianismo, conforme entendido por Eusébio.

\footnotetext{
${ }^{49}$ Idem p. 268

${ }^{50}$ Idem p. 269.
} 
O universo literário de Eusébio contou com a rica produção textual de Josefo. Por exemplo, diante de si ele tinha o Antigo Testamento, os escritos do próprio Flávio Josefo Antiguidades Judaicas, A guerra dos Judeus, o canônico livro Atos dos Apóstolos e o apócrifo Livro dos Macabeus. Com esse material Eusébio produziu uma nova história preocupada com a continuidade da história da igreja. Assim, uma "narrativa própria da história" ${ }^{51}$, desde a formação até o progresso do cristianismo e seu proselitismo pelo mundo conhecido. Ele tinha a visão que os cristãos eram mártires, "testemunhas heroicas da verdade". Em seus escritos, Eusébio incorporou a perspectiva de Josefo, que os romanos eram perseguidores dos judeus. Acrescentou a ela uma visão de que os próprios judeus também eram perseguidores dos cristãos.

O fato de que o livro de Atos dos Apóstolos, não possui uma conclusão, permitiu que Eusébio usasse-o para dar seguimento na ideia de sucessão de nação santa, do povo escolhido. Para ele, os discípulos de Cristo não apenas expandiram o cristianismo e expuseram os hereges, mas também lançaram as bases para a nova história da igreja. Afinal, os bispos deram continuidade a sucessões apostólicas dos herdeiros do Salvador. Aliás, a ideia de Josefo sobre heresia era bem diferente presente na tradição cristã, o qual Eusébio estava inserido. Para Josefo heresia era uma escolha filosófica, como já vimos antes.

No contexto cristão, Eusébio escreve sua obra rompendo com a historiografia clássica com a necessidade de testemunhos oculares. Ele inaugura uma historiografia eclesiástica que tem como fonte textos antigos. Ele estabeleceu um novo método de escrever história. Tomando como testemunho os escritos antigos e interrogando testemunhas contemporâneas. Ao usar suas fontes Eusébio fala sobre o critério de escolha dos seus testemunhos, chamando por ele mesmo de florilégio, algo que François Hartog comenta em suas observações sobre Eusébio ${ }^{52}$. Isso é notável porque Eusébio não fez apenas um apanhado aleatório de escritos. Ele vai como que coletando flores para um buquê; escolhendo os textos dos que escreveram antes dele, que melhor se harmonizavam com sua narrativa histórica. Não havia

\footnotetext{
${ }^{51}$ Idem p. 257.

${ }^{52}$ HARTOG, idem 2, p. 268
} 
necessidade de autópsia das fontes. Ele considerava tudo como puro e digno de ser consultado e apropriado.

A história da igreja em Eusébio foi uma história vitoriosa, como a história da própria nação de Israel, o povo escolhido. A continuidade era herança legítima deixada por uma nação antiga para sua sucessora. A história da nova nação cristã escolhida diante do mundo. Agora com Jesus, o salvador, e os 12 apóstolos. Ele usa o conceito de sucessão sendo este o próprio eixo da sua narrativa. Assim, sem a sucessão vinda do povo de Israel composto pelas 12 tribos de Jacó, passada agora para os 12 apóstolos cristãos e em seguida para os bispos como sucessores regulares, seria impossível uma sequência dotada de um caráter autêntico, instituído e de plena autoridade da igreja.

Eusébio se tornou referência por sua conceituada obra intitulada História Eclesiástica. São dez volumes, publicados por volta de 324 EC. Foi considerada a história eclesiástica mais importante escrita na antiguidade. Comentando sobre a grande autoridade que Eusébio conquistou entre a historiografia antiga e sobre a estrutura da documentação presente em História Eclesiástica, Arnaldo Momigliano (2004, p.198) diz: “foi um dos protótipos mais confiáveis criados pelo pensamento antigo". 53

Nesta pesquisa e na sua trajetória, vamos dar atenção a História Eclesiástica devido à sua contribuição na preservação de obras antigas e comentários, que de outra forma estariam perdidos, caso ele não tivesse feito uso. Eusébio nesta obra narra os acontecimentos em paralelo com a sucessão de bispos e imperadores romanos. Também transcreve textos bíblicos comentados e extensas citações de fontes. Nosso foco será e a interpretação do ataque de Céstio Galo junto com seu exército no ano 66 E.C, da destruição final da cidade de Jerusalém e do templo no ano 70 E.C, já liderada por Tito. Também daremos atenção a passagens textuais as quais Eusébio exalta a providência divina controlando o rumo dos acontecimentos, desde o fim da cidade sagrada e do templo até início da uma nova era cristã.

${ }^{53}$ MOMOGLIANO, Arnaldo. As Raízes Clássicas da Historiografia Moderna.EDUSC. Bauru, SP. 2004. 


\title{
Parte 2.1 O evento narrado por Eusébio
}

Logo no início vale ressaltar que a narrativa é feita a partir do ponto de vista do fiel cristão. Eusébio via a necessidade de relacionar os eventos locais e temporais ao caráter transcendente e sucessivo da Igreja. Ele próprio explica seu pressuposto ao professar ser cristão ao declarar Cristo como seu Salvador.

Eusébio escreveu (L.I. cap.I,§1,2):

\begin{abstract}
"É meu propósito consignar as sucessões dos santos apóstolos e os tempos transcorridos desde nosso Salvador até nós; o número e a magnitude dos feitos registrados pela história eclesiástica e dos que nela se sobressaíram no governo e presidência das igrejas mais ilustres, assim como o número daqueles que em cada geração, de viva voz ou por escrito, foram os embaixadores da palavra de Deus... e mais, inclusive as desventuras que se abateram sobre toda a nação judia depois que concluíram sua conspiração contra nosso Salvador" ${ }^{54}$.
\end{abstract}

Eusébio registra os grandes feitos realizados pelos homens, em relação a história da igreja, como a nação dos cristãos. As desgraças não foram reveses da fortuna, mais, sim, ação direta da providência divina.

Semelhante a Josefo, testemunha da última guerra dos romanos contra os judeus, Eusébio presenciou a última perseguição dos romanos aos cristãos. Ele se apropriou dos escritos de Josefo para dar continuidade da história do povo escolhido no livro dois de História Eclesiástica. A identificação do Messias, a propagação da palavra de Deus ao mundo e a interpretação dos acontecimentos fazem parte da narrativa. Era a providência divina que dava força e assistência aos ocorridos, neste ponto, Eusébio e Josefo não seriam diferentes.

${ }^{54}$ CESAREIA, Eusébio de. História Eclesiástica. Trad. Wolfgang Ficher. Novo Século. São Paulo. 2002. 
Para o fiel Eusébio, o cristianismo, com seu culto e práticas, era a religião de Deus "que nosso salvador semeou na vida dos homens". ${ }^{55}$ Quem se opunha a esta religião se colocava contra o próprio Deus.

O testemunho de Cristo foi alvo de hostilidade, assim como sofreriam os santos apóstolos, os quais por todas as nações multiplicavam seu ministério, mesmo quando dispersados pelos perseguidores. E não apenas isso, junto a perseguição dos justos, estava profetizado grandes calamidades, que comporiam um sinal claro da desaprovação de Deus aos judeus, e castigo pelos seus crimes: fomes, terremotos, sinais no céu e vistas aterrorizantes. Eventos que aconteceriam antes do castigo final contra o povo que rejeitou o cordeiro de Deus.

Falando nas calamidades, elas aumentaram no tempo de Caio (Calígula). Caio se proclamou deus e desestruturou o império com seus desmandos. Fílon de Alexandria, importante filósofo judeu-helenista, embaixador junto a Caio, foi em defesa dos judeus e das leis pátrias do povo. Fílon apesar de ser capaz de defender os judeus, acusados por meio de calúnias, foi ridicularizado em público por isso. Essa ação causou a expulsão dele por Caio da embaixada que ele mesmo presidia.

Fílon tentou animar os judeus da sua comitiva, dizendo que a fúria de Caio apesar de parecer contra eles, na verdade era contra Deus ${ }^{56}$. Porém para Eusébio, todas as calamidades que sobrevinham aos judeus ocorreram desde que eles (os próprios judeus) tinham pedido a morte do Salvador, o chamado Jesus Cristo. Por isso, Eusébio escreveu que as desgraças contra os judeus foram "prova definitiva das desventuras que ao mesmo tempo ou em rápida sequência caíram sobre os judeus por causa dos crimes contra Cristo". 57

Eusébio interpretou que o ódio do imperador era mais violento contra a raça judia. Os judeus achavam um ultraje honrar Caio com suas estatuas e jurar pelo seu nome. Caio não apenas invadiu e se apoderou das sinagogas, mais do que isso, encheu-as de imagens da sua própria figura. Jerusalém e o templo, antes espaços invioláveis, foram transformados em Templo de Caio, Novo Zeus Epifano. Essa sequência dos

\footnotetext{
${ }^{55}$ CESAREIA, Eusébio. História Eclesiástica. Trad. Wolfgang Ficher. Novo Século. São Paulo. 2002. P.51

${ }^{56}$ L.II, cap. V, $\$ 5$

${ }^{57}$ L.II, cap. V, §6
} 
“infortúnios que caíram sobre toda a raça judia tiveram início nos tempos de Pilatos e dos crimes contra o Salvador". ${ }^{58}$

Os imperadores e governadores que contribuíram para os males espirituais e físicos do povo, não ficariam sem sua punição. Primeiro Tibério envia Pilatos como procurador à Judeia à noite. Ele introduz na cidade efígies de César, tornando a cidade sagrada impura e aos judeus ficaram horrorizados. Pilatos gastou o tesouro do templo com construção do aqueduto, deixando o povo mais enfurecido. As agitações e revoltas dos judeus continuaram por um tempo e foram sendo vencidas pouco a pouco com repressões, violências e mortes. Por fim, a justiça de Deus os esmagou por completo. A punição cabal alcançou os judeus pelos seus crimes contra o Cristo em 70EC.

Como nem os poderosos de Roma eram protagonistas destes fatos, e nas mãos do Todo Poderoso estava todo o controle da vida material e imaterial, a punição pelos seus atos de soberba e violência não passaram despercebidos aos olhos de quem tudo vê.

Primeiro Pilatos se viu envolvido em tempo de grandes calamidades e forçado ao suicídio. Depois o imperador Claudio, que sucedeu a Caio, passou pelo período de grande fome, como predito pelo cristão Ágabo no livro de Atos dos Apóstolos 11:28 que diz: "Um deles, chamado Ágabo, levantou-se e predisse, por meio do espírito, que uma grande fome estava para vir sobre toda a terra habitada. De fato, ela ocorreu no tempo de Cláudio". 59

Por fim, Herodes perseguidor implacável dos apóstolos, que eram considerados embaixadores de Cristo e do seu reino celestial, não ficou sem punição. Num certo dia na Cesareia, vestido de esplendor régio, diante de uma tribuna, em cima do palco, Herodes era aplaudido como se fosse um deus. Enquanto ainda se gabava, foi atingido por um anjo que lhe causou uma dor mortal. Agonizou durante cinco dias e, por fim, morreu aos 54 anos de idade.

Voltamos as calamidades que sofreriam os judeus descritas por Josefo em Antiguidades Judaicas livro XX, que Eusébio recuperou em sua obra História

\footnotetext{
${ }^{58}$ L.II, cap. VI, $\$ 3$

59 Tradução do Novo Munda da Bíblia Sagrada. Ed. Associação Torre de Vigia de Bíblias e Tratado São Paulo. 2016.
} 
Eclesiástica. Uma divisão interna entre os judeus causou muitas mortes violentas. Cada um dos principais sacerdotes criou para si um grupo de rebeldes e atrevidos. Estes se enfrentavam com insultos e violência; causando entre si e entre o povo ainda mais divisões. Em dias de festa, escreve Eusébio, transcrevendo o relato Josefo (L.II, cap.XX, §5):

"Misturavam-se à multidão levando adagas escondidas sob as roupas e com elas apunhalavam seus adversários. Quando estes caíam, os próprios assassinos uniam-se aos que manifestavam sua indignação, e por isso, com tal aparência de honradez, não havia quem os descobrisse".

Esses que postavam adagas ou sicae, também eram conhecidos por sicários, ou seja, aquele que mata com adaga e pelas costas. As iniquidades destes chegaram a ser interpretadas por Josefo e Eusébio, como a principal causa da destruição de Jerusalém. O império romano estava farto dos atos de violência e perturbação da ordem promovida por esses agitadores. Sua fama era bem conhecida em toda a Judeia. Um destes líderes armado com adagas ficou bem conhecido como 'O Egípcio', sendo registrado também nos Atos dos Apóstolos, por Josefo e transcrito por Eusébio.

A culpa do povo judeu foi se agravando com o martírio dos apóstolos, por sua corrupção política e por sua violência. Perseguiram e acusaram Paulo, Tiago, Pedro e Estevão. Tiago, conhecido como irmão de Jesus, confessou perante o povo sua fé e foi morto. Isso se deu porque os judeus se aproveitaram que estavam sem governante, na ocasião estava em andamento a troca de autoridades, e a atual ainda não havia chegado a cidade.

Por nenhum outro motivo, senão por terem cometido o crime de matar um homem justo, Tiago; veio também a vingança divina contra eles em 70 E.C ${ }^{60}$. Mais uma vez a justiça de Deus atuou sem falhar. Nesse assunto, Eusébio fez questão de mencionar que Josefo atestou o sofrimento dos judeus como vingança da parte de Deus. Ele escreveu: "Isto sucedeu aos judeus como vingança por Tiago, O Justo,

${ }^{60}$ L.II, cap.XXIII,§19 
irmão de Jesus, o chamado Cristo, porque exatamente os judeus o mataram, ainda que fosse um homem justíssimo". ${ }^{61}$ (*)

Paulo e Pedro foram assassinados na mesma época pelo proclamado inimigo de Deus, Nero. No seu afã homicida, mandou matar parentes, inclusive sua própria mãe. Segundo Eusébio, "foi o primeiro que se mostrou inimigo da piedade para com Deus”. (L.II, cap.XXV,§2). Decapitou Paulo e crucificou Pedro. Seus túmulos se tornaram troféus que supostamente fundariam a futura igreja.

Por toda a parte, surgiu uma onda de ódio contra a revolta dos judeus. Os habitantes de todas as cidades os tratavam sem piedade. Parece que para Eusébio, os últimos meses que antecederam a destruição da cidade sagrada e dos dias finais daquela geração, tudo estava confluindo para uma solução definitiva. Todos os acontecimentos mostravam que algo viria mudar definitivamente e que não ocorreria outra vez.

${ }^{61}$ L.II, cap.XXIII, $\S 4,5(*$ Desconhece-se este trecho nos manuscritos de Flavio Josefo, como Eusébio, contrário a seu costume, não cita obra e livro, pode tê-la recolhido de outro autor, como Orígenes). 


\subsection{Eusébio, as profecias e a providência divina}

No último capítulo XXVI $§ 1$, Eusébio descrevendo que o testemunho de Josefo, localiza o tempo em que se ascendeu a última guerra, "no décimo segundo ano do império de Nero", por volta de 66 E.C, o procurador da Judéia, Floro, açoitou e crucificou muitos judeus importantes. Depois desta última revolta, provavelmente em 67 E.C, rebelião esta que Josefo foi preso pelos romanos, toda a região da Síria foi tomada por uma espantosa confusão. Isto envolvia um enorme grau de ódio contra os judeus por todas as partes.

Seguindo sua narrativa no Livro III, Eusébio associa o assassinato de Estevão, já mencionado, ao que logo aconteceria em consequência pela morte injusta de mais um fiel: uma terrível fome.

Em 68 E.C, Vespasiano assume como senhor absoluto após 13 anos do reinado de Nero. Destacado nas armas bélicas, nomeado imperador encaminha-se de volta a Roma e delega ao seu filho Tito à guerra contra os judeus. Enquanto este se aproxima, a fome estava oprimindo os judeus de forma agressiva. Os apóstolos continuavam sendo perseguidos e assassinados, sendo expulsos da terra da Judeia. Ameaçados de morte por onde passavam, mas, continuavam, com o poder de Cristo a dirigirem seus passos para as nações para ensinar a mensagem. ${ }^{62}$

A escassez de alimento foi predita também pelos profetas e pelo Cristo. E fazia parte do castigo divino por perseguirem os que haviam aceitado Jesus. Mais uma vez, citando e transcrevendo Josefo, Eusébio relata (L.III, cap. VI, § 2):

"O trigo estava invisível, mas eles invadiam as casas e as revistavam. Então se o encontravam, maltratavam-nos por ter negado; se não o encontravam, torturavam-nos por tê-lo escondido tão cuidadosamente. A prova de o ter ou não ter eram os corpos dos desgraçados: os que ainda se aguentavam em pé pareciam ter alimentos em abundância; os que já estavam consumidos eram deixados em paz: parecia fora de propósito matar alguém que logo morreria de inanição".

\footnotetext{
${ }^{62}$ L.III, cap. V,§ 1,2
} 
Os corpos pela fome estavam desfigurados. Os víveres eram trancados na parte mais oculta da casa. Eusébio continua o relato de Josefo da situação cada dia mais desesperadora. "Tiravam do fogo a comida ainda crua e a devoravam; $\mathrm{O}$ alimento era miserável e o espetáculo deplorável” (L.III, cap. VI, § 4,5).

A fome destruiu os corpos e a dignidade. Mulheres tiravam alimento da boca dos maridos; filhos da boca dos pais; e mães das bocas dos filhos. Se uma casa estava fechada muito tempo, era sinal que tinha comida dentro. Logo, esfomeados arrombavam as portas e arrancavam os bocados de quem fosse. Procuravam grãos de legumes em todo esconderijo possível. O que parecia mais absurdo era feito para se encontrar comida. Por exemplo: "Usavam espantosos métodos de tortura para descobrir comida: obstruíam a uretra dos desgraçados com grãos de legumes e trespassavam-lhes o reto com varas pontiagudas.” (L.III, cap.VI, §8)

A necessidade os fez comerem alimentos impróprios até para os animais repugnantes. Comiam calçados, cintos e escudos de couro. Em cada casa havia brigas e grande violência. Nem os corpos dos mortos ou moribundos escapavam de revistas por grãos de comidas. Muitos caíam mortos junto com os que tinham acabado de enterrar. Tito ao fazer ronda e ver essa calamidade, levantou a mão a Deus como sua testemunha de que aquilo não era obra sua.

A última desgraça possível que ainda faltava na tragédia dos judeus, envolveu uma mulher chamada Maria. O relato dramático feito de Eusébio usando Josefo como fonte diz (L. III, cap.VI, §21-27):

"Uma mulher das que habitavam na outra margem do Jordão, chamada Maria, filha de Eleazar, da aldeia de Batezor - nome que significa "casa de hissopo" - notável por suas riquezas e sua linhagem, fugiu para Jerusalém com o resto da multidão e com esta compartilhava o assédio.

Os tiranos tiraram-lhe todos os seus bens que havia reunido e levado consigo à cidade desde Pereia...o pouco alimento que encontraram foi sendo roubado por pessoas armadas que entravam a cada dia. Foi grande a indignação daquela pobre mulher, que muitas vezes injuriava e maldizia os ladrões para excitá-los contra si mesma.

Mas como ninguém a matava ... com as entranhas e a medula trespassada pela fome, tomou conselheiras a cólera e a necessidade e se lançou contra a natureza, agarrou o filho que 
tinha - criança ainda de peito - e disse: Criatura desgraçada! Em meio à guerra, à fome e à revolta, para quem vou guardar-te? Entre os romanos...a escravidão; mas a fome se antecipa à própria escravidão e os rebeldes são piores do que ambas as coisas. Eia! Seja alimento para mim, maldição para os rebeldes e fábula para o mundo: a única que faltava às calamidades dos judeus"!

A continuação do registro de Eusébio, comenta que enquanto a mulher falava, matou e assou o filho. Comeu uma parte e a outra escondeu. Logo os rebeldes chegaram e perceberam que a mulher tinha preparado algo para comer. Ameaçaram-na que se não mostrasse a porção seria degolada. Ela disse a eles que havia guardado a melhor porção, e revelou que era o que restara do seu filho, dizendo: "é meu filho e eu o fiz. Comei, pois também eu comi. Não sejais mais brandos do que uma mulher nem mais compassivos do que uma mãe" (L.III, cap.VI, $\S 26)$.

A cidade inteira ficou horrorizada. Os famintos tinham pressa para morrer, ainda mais depois de ouvirem relatos como esse. Finalizando essa calamidade, Eusébio expõe sua interpretação, ao dizer: "Esta foi a recompensa dos judeus por sua iniquidade e impiedade para com o Cristo de Deus” (L.III, cap. VI, §28).

Dedicando o capítulo VII às profecias de Cristo, Eusébio acrescenta o relato do evangelho de Lucas 21:11 que diz: “e haverá grandes terremotos, e, num lugar após outro, pestilências e escassez de víveres; e haverá vistas aterrorizantes e grandes sinais do céu".

Neste mesmo capítulo ainda encontramos os relatos de Mateus 24:19-21 e Lucas 21:11, respectivamente, que dizem:

\footnotetext{
"Ai das mulheres grávidas e das que amamentarem naqueles dias! Persistam em orar para que a sua fuga não ocorra no inverno nem no sábado; pois então haverá grande tribulação, como nunca ocorreu desde o princípio do mundo até agora, não, nem ocorrerá de novo". ${ }^{63}$
}

${ }^{63}$ Tradução do Novo Munda da Bíblia Sagrada. Ed. Associação Torre de Vigia de Bíblias e Tratado São Paulo. 2016 
"Haverá grandes terremotos e, num lugar após outro, falta de alimento e pestilências, e as pessoas verão coisas atemorizantes e grandes sinais do céu". ${ }^{64}$

Além da fome, Eusébio transcreve outros sinais que ocorreram antes da destruição da cidade e do templo narrados por Josefo. Esses sinais estão de acordo com as palavras do Salvador registradas no evangelho de Mateus e de Lucas citados acima.

Eusébio diz (L.III, cap. VIII, §1-8):

"Toma pois, e lê o que apresenta no Livro VI de suas Histórias com estas palavras:

'Naquele tempo, os impostores e os que levantavam tais calúnias contra Deus, pervertiam o povo miserável, de forma que nem percebiam nem davam crédito a tais prodígios bem claros que anunciavam de antemão a iminente desolação; como se aturdidos por um raio e como se não tivessem olhos nem alma, faziam ouvidos surdos às mensagens de Deus.

Estas foram: um astro que se deteve sobre a cidade, semelhante a uma espada de dois gumes, e um cometa que durou todo um ano... estando o povo reunido para celebrar a festa dos ázimos, no oitavo dia do mês de Jantico, à nona hora da noite, brilhou sobre o altar e o templo uma luz tão grande que poder-se-ia pensar que era dia....

Na mesma festa, uma vaca que o sumo sacerdote conduzia ao sacrifício pariu um cordeiro no meio do templo.

E a porta... que era de bronze e muito pesada, e que havia sido fechada ao anoitecer com dificuldade por vinte homens que a trancaram solidamente com ferrolhos presos com ferro, abriu-se sozinha à sexta hora da noite.

E passada a festa, apareceu um fantasma demoníaco de tamanho incrível. De fato, antes do pôr-do-sol, apareceram pelo ar em redor de toda a região carros e falanges armadas que se lançavam através das nuvens e rodeavam as cidades.

E na festa de Pentecostes, à noite, entrando os sacerdotes no templo... perceberam movimento e ruído de golpes, e logo um grito em uníssono: Saiamos daqui!

E o mais terrível: um homem chamado Jesus, filho de Ananías, homem simples, camponês, quatro anos antes da guerra, quando a cidade desfrutava da maior paz e do máximo esplendor, veio a festa, pois era costume que todos erigissem tendas em honra a Deus, e de repente começou a gritar pelo templo: Voz do oriente!

${ }^{64}$ Idem 6 
Voz do ocidente! Voz dos quatro ventos! Voz de Jerusalém e sobre o templo! Voz de recém-casados e casadas! Voz sobre todo povo! Dia e noite gritava isso por todas as vielas... alguns cidadãos irritados com seus agouros, prenderam o homem e maltrataram-no, enchendo-o de feridas...continuava gritando aos presentes o mesmo que antes".

Após os sinais que ocorreram antes da destruição da cidade, no segundo ano do império de Vespasiano (exatamente em setembro do ano 70 E.C), ${ }^{65}$ veio a destruição. Eusébio exalta a infalível predição de Cristo, que pelo poder divino havia profetizado, escrito em Luc.19:42-44, Luc.21:23-24, Luc. 21:20, respectivamente.

Lemos:

\begin{abstract}
"Se tu conheceras ao menos neste dia o que diz respeito a tua paz! Mas agora está oculto aos teus olhos. Porque virão dias sobre ti, e teus inimigos te rodearão de paliçadas, te cercarão e por todos os lados te apertarão. E te assolarão a ti e a teus filhos. E outras como referindo-se ao povo: Porque haverá grande necessidade sobre a terra e ira contra este povo. E cairão ao fio da espada e serão levados cativos a todas as nações. E Jerusalém será pisoteada pelos gentios, até que sejam cumpridos os tempos destes povos. E outra vez: E quando virdes Jerusalém cercada por exércitos, sabei então que terá chegado sua desolação".
\end{abstract}

Ao comparar os registros de como se deu o cerco final e a tomada da cidade de Josefo com as palavras do evangelho, Eusébio acredita ter sido "verdadeiramente divinas e sobrenaturalmente prodigiosas". ${ }^{66}$ Ressaltando a paciência divina por tolerar por cerca de quarenta anos após o crime contra seu Cristo. As legiões romanas, seu imperador e generais foram usados para mostrar o poder de Deus e sua capacidade de agir segundo sua vontade.

Por fim, pela fome ou depois pela espada, os judeus mortos no ataque final contra Jerusalém, somaram um milhão e cem mil. Incluindo os rebeldes executados pela espada, os jovens belos reservados para serem exibidos e mortos na cerimônia de triunfo, e os que seriam mortos nos teatros pela espada e pelas feras para a diversão dos romanos. Só sobrariam vivos os menores de 17 anos que seriam vendidos ou

${ }^{65}$ L.III, cap.III, $\$ 3$ (nota)
${ }^{66}$ Idem 16, $\$ 6$ 
escravizados. O que seguiu nos anos seguintes a 70 E.C, configurou o início da nova nação.

Eusébio acreditava e interpretava os acontecimentos para que desse uma harmonia a continuidade da história inicial da igreja. O relato mostra que depois da ascensão do Cristo, os anos seguintes foram também os anos de uma intensa campanha de pregação dos apóstolos, acompanhada de severa perseguição e seguida da morte de cada um deles.

Sua narrativa sobre a mudança dos judeus cristãos para a região montanhosa, por ocasião do cerco de Jerusalém em 66 E.C, foi a que possivelmente explica como que os fiéis cristãos, por obedeceram ao aviso profético de Jesus, dito anos antes, de sair de Jerusalém. Assim salvaram suas vidas e asseguraram o destino e a continuidade da comunidade cristã de Jerusalém que havia sido ameaçada com a morte de Tiago, irmão de Jesus, e as perseguições contra os outros apóstolos.

Eusébio narrou:

\begin{abstract}
"Depois da ascensão de nosso Salvador, os judeus acrescentaram ao crime cometido contra ele a invenção de inúmeras ameaças contra seus apóstolos: Estevão foi o primeiro que eliminaram, apedrejando-o; depois dele, Tiago, filho de Zebedeu e irmão de João, a quem decapitaram; e depois de todos, Tiago, o que depois as ascensão de nosso Salvador foi o primeiro designado para o trono episcopal de Jerusalém e morreu da forma como já descrevemos. Os demais apóstolos sofreram milhares de ameaças de morte e foram expulsos da terra da Judeia". ${ }^{67}$
\end{abstract}

No evangelho de Mateus 24:15 Cristo estava citando as palavras do livro bíblico de Daniel 9:27, ao dizer que quando seus discípulos vissem "a coisa repugnante que causa desolação", os exércitos romanos cercando Jerusalém, a única salvação seria saírem da cidade e irem para os monte, ficarem longe daquela região.

Eusébio interpretou que a profecia messiânica sobre a destruição de Jerusalém, também influenciou a saída dos judeus cristãos.

\footnotetext{
${ }^{67}$ L.III, cap. V,§2
} 
Ele escreveu:

“Também o povo da igreja de Jerusalém, por seguir um oráculo enviado por revelação aos notáveis do lugar, receberam a ordem de mudar de cidade antes da guerra e habitar certa cidade da Peréia, chamada Pella. Tendo os que creram em Cristo emigrado até lá desde Jerusalém, a partir deste momento, como se todos os homens santos tivessem abandonado por completo a própria metrópole real dos judeus e toda região da Judéia, a justiça divina alcançou os judeus pelas iniquidades que cometerem contra Cristo e seus apóstolos, e apagou dentre os homens toda aquela geração de ímpios”. 68

Vimos que Eusébio associava os relatos de Josefo paralelamente com as profecias nas escrituras hebraicas e as de Cristo registrados nos Evangelhos. Isso fazia parte da sua narrativa, afinal ele colheu os testemunhos que se harmonizaram com seu argumento baseado na sucessão. Os que não voltaram para Jerusalém até o fim do castigo escaparam da morte. Seja porque escaparam das inúmeras guerras civis entre as facções judaicas dentro de Jerusalém, seja porque não estavam na cidade quando Tito retornou em 70 E.C com a destruição total.

Eusébio não faz uma narração da tomada de Jerusalém, nem dos males sofridos pelos seus habitantes da Judeia; e as inúmeras formas de morte; quais e quantas cidades foram sitiadas e incendiadas; dos horrores que atingiram os que se refugiaram dentro da própria Jerusalém; os acontecimentos abomináveis dentro do templo de Deus anunciada pelos profetas; e nem da destruição pelo fogo do templo sagrado. Para tal, Eusébio incentiva a consultar os escrito na narrativa de Josefo. Ele faz apenas uma ressalva quanto ao número dos que se encontravam na cidade, por ocasião da tomada que coincidiu como os dias da festa da Páscoa, 3.000 .000 de pessoas.

Eliminando aquela geração corrompida, dava-se a partida para o reinício da nova igreja salva pela fé e pela obediência a Cristo. Os cristãos continuariam com sua

${ }^{68}$ L.III, cap.V, $\S 3$ 
mensagem de salvação por meio de Jesus, orientados pelos bispos que receberiam autoridade para tal, segundo a lógica da sucessão apostólica. 


\section{3 - Considerações finais}

Após considerarmos os escritos de Josefo e Eusébio sobre o período crucial para a nação judia no primeiro século da nossa era, entendemos que o sentido da História Universal. Esta sempre esteve, para eles, amparada na vontade do Deus Criador, e seguiu os rumos estabelecidos e direcionados pelo mesmo.

As desgraças sofridas pelo povo hebreu, para Josefo teve uma razão para a tal. Josefo enfatizava um padrão de comportamento do povo eleito demostrado desde seus primórdios. A relação com o seu Deus, ora libertador, ora punidor estava presente em toda história dos judeus. A intensidade dos males que aquela geração sofreu, era correspondente ao seu comportamento cruel e violento.

Sempre que havia um desvio referente à adoração para com seu deus, os pecados cometidos pelos hebreus eram expostos por meio das mensagens de julgamento, seguido das punições e de castigos. Eles, mediante algum arrependimento após sofrerem, recebiam a misericórdia e o perdão do seu Deus. Assim, para Josefo o que ocorreu com o povo nos últimos anos que antecederam a destruição da cidade de Jerusalém e do templo, obedeceu este mesmo critério de interpretação. Como foram muito graves os erros da nação, divisões internas, falsos presságios, profanação do templo, no mesmo grau se esperava que fosse a disciplina.

Para Eusébio, a ênfase nas desgraças, e a extensa narrativa das calamidades advindas sobre os judeus servia-lhe para corroborar seu principal argumento. Os erros daquela geração estavam vinculados à morte do Salvador e a perseguição e assassinato dos apóstolos. Como vimos, Eusébio associa que desde que Jesus iniciou sua pregação iniciando o ajuntamento de discípulos, iniciou-se em Jerusalém uma onda de perseguição que culminou no martírio do primeiro bispo, Tiago, e na saída dos judeus cristão de Jerusalém para Pella. O que se seguiu dentro da cidade, não afetou o novo povo de Deus, somente aos ímpios a qual cabia receberem punição pelos seus atos.

Apesar de Josefo não dar uma continuidade, e nem tentar vislumbrar qual seria o destino dos judeus após e catástrofe de 70, tudo nos indica que ele continuou 
convicto que mesmo com tudo que havia acontecido, a eleição do povo nunca foi posta em ameaça, e que seu caráter de nação ungida permaneceria.

Eusébio deu a continuidade do destino do novo povo eleito no restante dos escritos na sua História Eclesiástica, afinal, o favor divino foi transferido para a nova nação cristã. Depois do ocorrido em Jerusalém em 70, Eusébio escreve que os judeus cristãos voltaram para a cidade e estabeleceram a comunidade cristã elegeram o sucessor para o primeiro bispo, um homem chamado Simeão. ${ }^{69}$ Mais uma vez, a história do povo eleito, inserido na história universal, foi uma história vitoriosa.

Josefo no seu esforço de alcançar os judeus com suas obras exaltando a superioridade do povo judeu, não alcançou sua vontade. Pelo contrário, suas obras foram rejeitadas pela comunidade judaica, e ironicamente apropriadas pela comunidade cristã. Seja como for, as obras de ambos os nossos autores continuam enriquecendo, até hoje, a pesquisa historiográfica .

${ }^{69}$ LIII, cap.V, §3 


\section{Bibliografia:}

- CESAREIA, Eusébio de. História Eclesiástica. Trad. Wolfgang Ficher. Novo Século. São Paulo. 2002.

- Grande Enciclopédia Barsa. $3^{a}$ Ed. Barsa Planet Internacional Ltda. São Paulo. 2004.

- HARTOG, François (org.). A História de Homero a Santo Agostinho.

Tradução de Jacyntho Lins Brandão. Belo Horizonte: Ed. UFMG, 2001.

- HUBEÑAK, Florencio. “Historia política y profecía: Roma y los grandes imperios antiguos a la luz de las predicciones del profeta Daniel” [en línea]. Hispania Sacra 48, nro. 97 (1996). Disponible en:

http://bibliotecadigital.uca.edu.ar/repositorio/contribuciones/historia-politicaprofecia-roma.pdf.

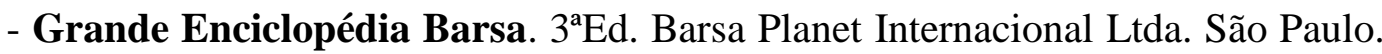
2004.

- JOSEFO, Flavio. A Guerra dos Judeus II. Tradução e adaptação de A.C.Godoy. Curitiba, Ed. Juruá, 2002.

- JOSEPHOS, Flavius. The Antiquities of the Jews. Books I-XIX. Translated by William Whiston. Disponible en: http://www.gutenberg.org/files/2848/2848h/2848-h.htm .

- JOSEPHOS, Flavius. The War of Jews. Books I-VII. William Whiston, A.M., ed., Disponible en:

http://www.perseus.tufts.edu/hopper/text?doc=Perseus\%3atext\%3a1999.01.0148,

- MOMigliAnO, Arnaldo. As Raízes Clássicas da Historiografia Moderna. Trad. Maria Beatriz Borba Florenzano. EDUSC, Bauru. São Paulo, 2004. 
- MOMIGLIANO, Arnaldo. Os limites da helenização. Trad. Claudia Martinelli Gama, Jorge Zahar Editora, Rio de Janeiro, RJ, 1991.

- PARADA, Maurício. Os Historiadores: Clássicos da História. Petropólis, RJ: Vozes; Rio de Janeiro: Ed. PUC-Rio, c2012.

- SIMON, Marcel; BENOIT, André. Judaísmo e Cristianismo Antigo. De Antíoco Epifâneo a Constantino. São Paulo. Pioneira; Editora da Universidade de São Paulo, 1987.

- Tradução do Novo Munda da Bíblia Sagrada. Ed. Associação Torre de Vigia de Bíblias e Tratado São Paulo. 2016. 